\title{
Comparison of minocycline and ampicillin in gonococcal urethritis
}

\author{
M. A. WAUGH,* E. MARY COOKE, $\uparrow$ B. B. G. NEHAUL, $†$ AND \\ JANET BRAYSON† \\ From the *Department of Genitourinary Medicine, Leeds General Infirmary, and the †Department of \\ Microbiology, School of Medicine, University of Leeds
}

SUMMARY A prospective, randomised, single-blind trial was carried out to compare the efficacy and tolerability of minocycline and ampicillin in the treatment of gonorrhoea in men. One hundred and twenty men were treated with minocycline $300 \mathrm{mg}$ and 121 men with ampicillin $2 \mathrm{~g}$ and probenecid $1 \mathrm{~g}$. Cure rates were similar in both groups of patients. There were few side effects.

Of 135 strains of Neisseria gonorrhoeae tested to different concentrations of minocycline and penicillin, two were resistant to penicillin (minimum inhibitory concentration (MIC) $\geqslant 0 \cdot 1 \mu \mathrm{g} / \mathrm{ml}$ ) and seven to minocycline (MIC $>1 \cdot 0 \mu \mathrm{g} / \mathrm{ml}$ ).

The incidence of PGU was $31 \%$ in those patients treated with minocycline and $34 \%$ in those treated with ampicillin plus probenecid, the difference not being statistically significant. PGU occurred more often after treatment with minocycline than in previous studies.

\section{Introduction}

Ampicillin has gained a place in the treatment of gonorrhoea since the early reports of Willcox (1963) and Alergant (1963). Used by itself there have been unacceptably high failure rates. Gundersen et al. (1969), as have others since, showed that the addition of probenecid, which blocks the renal excretion of penicillin causing a higher serum concentration, alleviated this problem. Adler (1978a) found that ampicillin was the most commonly prescribed antimicrobial for men with gonorrhoea in England and Wales, being used together with probenecid in onethird of clinics. It has no effect, however, when used as pivampicillin (Pondocillin) (an ampicillin derivative) on the development of PGU (Waugh and Nayyar, 1977). Minocycline hydrochloride, a semisynthetic derivative of tetracycline (7-dimethylamine6-deoxy-6-demethyl tetracycline hydrochloride), has been found to be of use in the treatment of gonorrhoea since the findings-albeit with differing results-of Pariser and Marino (1970) and Duncan et al. (1971). In the United Kingdom Shahidullah (1975) and Masterton and Schofield (1976) reporting its use

Address for reprints: $\operatorname{Dr}$ M. A. Waugh, Department of Genitourinary Medicine, General Infirmary, Great George Street, Leeds LS1 3EX

Received for publication 26 March 1979 in the treatment of uncomplicated gonococcal urethritis in men found incidences of PGU of $11.8 \%$ and $5 \cdot 1 \%$ respectively.

This study was carried out in 1977 and 1978 to compare (a) the efficacy and tolerability of minocycline and ampicillin in the treatment of uncomplicated urethral gonorrhea, and (b) the incidence of post-gonococcal urethritis (PGU) after treatment with these antimicrobials by means of a prospective, randomised, single-blind group comparative trial.

\section{Patients and methods}

Two hundred and forty-one men with acute gonococcal urethritis were randomly allocated to one of two single-dose treatment groups: group A received minocycline $300 \mathrm{mg}$; group B, ampicillin $2 \mathrm{~g}$ and probenecid $1 \mathrm{~g}$ taken with $210 \mathrm{ml}$ of water in the presence of a nurse. The drugs were given according to a previously designed randomisation code in identical containers only identifiable by the patient's number.

In all cases microscopical findings were verified by bacteriological culture. For primary isolation and for subculture a modified Thayer-Martin medium was used. The constituents were Oxoid GC agar base, a chemical enrichment, $1 \%$ Isovitalex (Baltimore Biological Laboratories, BBL), and $10 \%$ 
defibrinated horse blood instead of haemoglobin. Antibodies (vancomycin, colistin, and nystatin) were not added. The fermentation medium was cystinetrypticase peptone agar (CTA medium, BBL) with added carbohydrates. During most of the trial cultures for Chlamydia trachomatis were not taken routinely from male patients.

FOLLOW UP

After treatment the patients were asked to return at seven, 14, and 28 days, although this showed much personal variation. At all follow-up visits the patient had a urethral smear and culture and a two-glass urine test performed. If after seven days more than five pus cells per high power field ( $\times 100$ objective) were found in the urethral smear, or in shreds from centrifuged urine specimens, PGU was considered to be present. Patients were then treated with triple tetracycline (chlortetracycline hydrochloride $115.4 \mathrm{mg}$, tetracycline hydrochloride $115.4 \mathrm{mg}$, demeclocycline hydrochloride $69 \cdot 2 \mathrm{mg}$; Deteclo) one tablet twice daily for 14 days. The patient was clinically cured if his discharge and other symptoms of urethritis had disappeared and if Neisseria gonorrhoeae was not found on microscopy or culture.

On each return visit, the patient was asked if he had noticed any side effects of treatment and if he had had coitus recently.

Any patient who was allergic to penicillin or tetracycline, was a habitual defaulter, was suspected of having syphilis, or had been given antimicrobials in the previous two weeks was excluded.

\section{AGE, NATIONALITY AND PREVIOUS STD}

The mean age, standard deviation (years), nationalities, and previous history of STD of the two groups are shown in Table 1. The symptoms and signs of dysuria and discharge for the two groups are given in Table 2.

\section{DEFAULT RATE}

Of 241 patients in the trial, $199(82.6 \%)$ attended at least once after treatment. The duration of follow up is shown in Table 3.

\section{SENSITIVITY TESTS}

At the start of the trial 108 strains were overgrown with contaminants. A total of 135 strains were tested. Each isolate was confirmed as $N$. gonorrhoeae. Each strain was tested against both minocycline and penicillin. For each strain, isolated colonies from a 24-hour growth on modified Thayer-Martin medium without antibiotic were suspended in $1 \mathrm{ml}$ of trypticase soy broth (BBL) until a faintly turbid suspension was obtained. Using a calibrated loop,
Table 1 Details of patient groups

\begin{tabular}{lcl}
\hline & $\begin{array}{c}\text { Group } A \\
(n=120)\end{array}$ & $\begin{array}{l}\text { Group } B \\
(n=121)\end{array}$ \\
\hline Mean age (SD) & $27 \cdot 2(9 \cdot 3)$ & $26 \cdot 4(8 \cdot 3)$ \\
Country of origin & & \\
$\quad$ UK and Eire & 77 & 75 \\
West Indies & 24 & 26 \\
Others & 17 & 16 \\
Total & $118^{*}$ & $117 \dagger$ \\
Previous history of STD (\%) & $48(40)$ & $41(34)$ \\
\hline
\end{tabular}

* Two patients were reinfected during the trial

tFour patients were reinfected during the trial

Table 2 Symptoms and signs in patient groups

\begin{tabular}{|c|c|c|c|c|c|c|}
\hline & \multicolumn{3}{|c|}{ Group $A$} & \multicolumn{3}{|c|}{ Group B } \\
\hline & No. & $\%$ & $\begin{array}{l}\text { Mean duration } \\
\text { (days) }\end{array}$ & No. & $\%$ & $\begin{array}{l}\text { Mean duration } \\
\text { (days) }\end{array}$ \\
\hline $\begin{array}{l}\text { Dysuria } \\
\text { Discharge }\end{array}$ & $\begin{array}{r}78 \\
114\end{array}$ & $\begin{array}{l}65 \\
95\end{array}$ & $\begin{array}{l}3 \cdot 7 \pm 1 \cdot 8 \mathrm{SD} \\
5 \cdot 1 \pm 2 \cdot 4\end{array}$ & $\begin{array}{r}79 \\
115\end{array}$ & $\begin{array}{l}65 \\
95\end{array}$ & $\begin{array}{l}3 \cdot 8 \pm 1 \cdot 8 \mathrm{SD} \\
5 \cdot 8 \pm 2 \cdot 3\end{array}$ \\
\hline
\end{tabular}

Table 3 Duration of follow up in each treatment group

\begin{tabular}{llllll}
\hline & \multicolumn{4}{l}{ Duration of follow up (weeks) } & \\
\cline { 2 - 5 } Group & 0 & 1 & 2 & 4 & Total \\
\hline A & 20 & 32 & 29 & 39 & 120 \\
B & 22 & 28 & 29 & 42 & 121 \\
\hline
\end{tabular}

$1.0 \mu \mathrm{l}$ of the suspension was placed on the plate of diagnostic sensitivity test agar (Oxoid) with $7 \%$ lysed horse blood containing varying concentrations of penicillin and minocycline $(0 \cdot 06-1 \cdot 0 \mu \mathrm{g} / \mathrm{ml})$.

Plates were incubated for 48 hours in $\mathrm{CO}_{2}$ and the end point-that is, the minimum inhibitory concentration (MIC)-of each strain was taken as that concentration of antibiotic which resulted in no growth of the strain.

The Oxford staphylococcus was used as the control on each plate containing antibiotic.

\section{Results}

Recurrences in the two groups are shown in Table 4. A further analysis of total cure (no PGU or positive results to smears or cultures) is shown in Table 5.

\section{REINFECTION AND FAILURES \\ Group $A$}

In the period of four weeks after treatment, there were two treatment failures; a further two patients had probably been reinfected.

\section{Group B}

In this group, there were three treatment failures 
Table 4 Results of treatment

\begin{tabular}{|c|c|c|c|c|c|c|c|}
\hline \multirow[b]{2}{*}{ Group } & \multicolumn{3}{|c|}{ No. of patients } & \multirow{2}{*}{$\begin{array}{l}\text { \% negative follow } \\
\text { up and without } \\
P G U^{*}\end{array}$} & \multicolumn{3}{|c|}{ Treatment failures } \\
\hline & Treated & Followed up & Cured & & No. & $\%$ & Reinfected $\uparrow$ \\
\hline $\begin{array}{l}\text { A } \\
\text { B }\end{array}$ & $\begin{array}{l}120 \\
121\end{array}$ & $\begin{array}{r}100 \\
99\end{array}$ & $\begin{array}{l}65 \\
58\end{array}$ & $\begin{array}{l}54 / 120 \\
48 / 121\end{array}$ & $\begin{array}{l}2 \\
3\end{array}$ & $\begin{array}{l}1 \cdot 6 / 120 \\
2 \cdot 5 / 121\end{array}$ & $\begin{array}{l}2 \\
4\end{array}$ \\
\hline
\end{tabular}

*\% of total patients entered

†Based on all available clinical evidence and perusal of sexual partners' case histories

Table 5 Analysis of total cure*

\begin{tabular}{lllll}
\hline & \multicolumn{3}{l}{ Follow up (weeks) } & \\
\cline { 2 - 5 } Group & 1 & 2 & 4 & Total \\
\hline A & 26 & 21 & 18 & 65 \\
B & 22 & 19 & 17 & 58 \\
\hline
\end{tabular}

*Cure means no PGU and negative results to smears and cultures

(including one case of $\beta$-lactamase-producing $N$. gonorrhoeae). Four patients had probably been reinfected.

No correlation of sensitivities and treatment failures was made during the trial. However, we considered it of paramount importance to break the code of the case with $\beta$-lactamase-producing $N$. gonorrhoeae. The patient was a 38-year-old Ghanaian postgraduate student found to have treatment failure at seven days and was subsequently cured with spectinomycin $2 \mathrm{~g}$. He had no contacts in England and had left his wife in Accra, but her treatment could not be ascertained. The diagnosis was verified by $\operatorname{Dr}$ A. E. Wilkinson (Venereal Disease Reference Laboratory, London) on 29 June 1978 and reported to the World Health Organisation.

\section{POST-GONOCOCCAL URETHRITIS}

In group $\mathrm{A}, \mathrm{PGU}$ occurred in 31 of 100 patients followed up. In group B it occurred in $34(34 \cdot 3 \%)$ of 99 patients followed up; the difference was not significant $\left(\chi_{1}^{2}=0 \cdot 12 ; \mathrm{P}>0 \cdot 5\right.$, Yates's modification).

\section{SIDE EFFECTS}

\section{Group $A$}

One patient reported vomiting after medication but on follow up was found to be cured.

\section{Group B}

One patient developed a widespread purpuric eruption after 48 hours and was found to have glandular fever; one other developed candidal balanoposthitis within a week of treatment.

\section{RESULTS OF SENSITIVITY TESTS}

These are shown in Table 6.

\section{Penicillin}

Strains which were considered to be fully sensitive had an MIC of $<0 \cdot 1 \mu \mathrm{g} / \mathrm{ml}$, those with a reduced
Table 6 Minimum inhibitory concentrations of minocycline and penicillin for 135 isolates of Neisseria gonorrhoeae

\begin{tabular}{|c|c|c|c|c|c|c|c|}
\hline \multirow{2}{*}{$\begin{array}{l}\text { MIC of } \\
\text { minocyclin } \\
(\mu \mathrm{g} / \mathrm{ml})\end{array}$} & \multicolumn{6}{|c|}{ No. of strains with MIC of penicillin $(\mu \mathrm{g} / \mathrm{ml})$} & \multirow[b]{2}{*}{ Total } \\
\hline & 0.06 & $0 \cdot 12$ & $0 \cdot 25$ & 0.5 & $1 \cdot 0$ & $>1 \cdot 0$ & \\
\hline $\begin{array}{l}0.06 \\
0.12 \\
0.25 \\
0.5 \\
1.0 \\
>1.0 \\
\text { Total }\end{array}$ & $\begin{array}{r}6 \\
35 \\
33 \\
17 \\
7 \\
2 \\
100\end{array}$ & $\begin{array}{r}1 \\
3 \\
10 \\
3 \\
1 \\
1 \\
19\end{array}$ & $\begin{array}{r}0 \\
1 \\
3 \\
4 \\
0 \\
2 \\
10\end{array}$ & $\begin{array}{l}0 \\
0 \\
0 \\
1 \\
1 \\
2 \\
4\end{array}$ & $\begin{array}{l}0 \\
0 \\
0 \\
0 \\
0 \\
0 \\
0\end{array}$ & $\begin{array}{l}0 \\
0 \\
0 \\
1 \\
1 \\
0 \\
2\end{array}$ & $\begin{array}{r}7 \\
39 \\
46 \\
26 \\
10 \\
7 \\
135\end{array}$ \\
\hline
\end{tabular}

sensitivity an MIC of $0 \cdot 1-0.5 \mu \mathrm{g} / \mathrm{ml}$, and those resistant an MIC of $>0.5 \mu \mathrm{g} / \mathrm{ml}$. One hundred strains were fully sensitive, 33 had a reduced sensitivity, and two were resistant.

\section{Minocycline}

Fully sensitive strains had an MIC of $<0.5 \mu \mathrm{g} / \mathrm{ml}$, those with a reduced sensitivity an MIC of 0.5-1.0 $\mu \mathrm{g} / \mathrm{ml}$, and those resistant an MIC of $>1 \cdot 0 \mu \mathrm{g} / \mathrm{ml}$. Ninety-two strains were fully sensitive, 36 had a reduced sensitivity, and seven were resistant.

\section{Discussion}

Both minocycline and ampicillin with probenecid were found to be effective forms of treatment, there being no significant difference in the outcome in either group.

There were minimal side effects and, as a result of careful history taking, no allergic reactions, although the well-known clinical picture of ampicillin rash in glandular fever was seen.

The default rate of $42(17 \cdot 4 \%)$ in 241 patients illustrates the importance of therapy that will be rapidly successful. It is probable that those patients who did not return were cured.

PGU rates $(31 \%$ for minocycline and $34.3 \%$ for ampicillin with probenecid) were higher than in a previous trial (Waugh and Nayyar, 1977), in which $33(23 \cdot 4 \%)$ of 141 men treated with pivampicillin $1400 \mathrm{mg}$ with probenecid $1 \mathrm{~g}$ had PGU. The diagnostic criterion was then more than 10 pus cells per high power field. Again the PGU rate of $31 \%$ for minocycline was much higher than that of $11.8 \%$ 
reported by Shahidullah (1975) and that of $5 \cdot 1 \%$ reported by Masterton and Schofield (1976). The observation of Adler (1978b) that there is no single criterion for diagnosing non-gonococcal urethritis is aptly illustrated when an attempt to compare PGU rates from different trials is made. A single dose of minocycline appears to have no effect on the prevention of PGU. The similarity of the PGU rates with both drug regimens, using the same criteria, strengthens this supposition.

We should like to thank Messrs Lederle Limited for supplying drugs used in this clinical trial.

\section{References}

Adler, M. W. (1978a). Diagnostic, treatment, and reporting criteria for gonorrhoea in sexually transmitted disease clinics in England and Wales. 2: Treatment and reporting criteria. British Journal of Venereal Diseases. 54, 15-23.
Adler, M. W. (1978b). Diagnostic, treatment, and reporting criteria for non-specific genital infection in sexually transmitted disease clinics in England and Wales. 1: Diagnosis. British Journal of Venereal Diseases, 54, 422-427.

Alergant, C. D. (1963). Treatment of gonorrhoea with Penbritin. A report of 200 cases. British Journal of Venereal Diseases, 39, 225-227.

Duncan, W. C., Glicksman, J. M., Knox J. M., and Holder, W. F. (1971). Treatment of gonorrhoea with a single oral dose of minocycline. British Journal of Venereal Diseases, 47, 364-366.

Gundersen, T., Odegaard, K., and Gjessing, H. C. (1969). Treatment of gonorrhoea by one oral dose of ampicillin and probenecid combined. British Journal of Venereal Diseases, 45, 235-237.

Masterton, G. and Schofield, C. B. S. (1976). Minocycline hydrochloride (Minocin) as a single-dose oral treatment of uncomplicated gonorrhoea in men. British Journal of Venereal Diseases, 52, 43-45.

Pariser, H. and Marino, A. F. (1970). One capsule treatment of gonorrhoea with minocycline. Antimicrobial Agents and Chemotherapy (Detroit), 10, 211-213.

Shahidullah, M. (1975). Single-dose treatment of uncomplicated gonorrhoea in males with minocycline. British Journal of Venereal Diseases, 51, 97-98.

Waugh, M. A. and Nayyar, K. C. (1977). Pivampicillin (Pondocillin) with probenecid (Benemid) in the treatment of gonorrhoea. Clinical Trials Journal (London), 14, 152-156.

Willcox, R. R. (1963). Ampicillin (Penbritin) in the treatment of gonorrhoea. British Journal of Venereal Diseases, 39, 164-167. 